\title{
Foreword
}

"The least initial deviation from the truth is multiplied later a thousand fold" is a saying by Aristotle. The equivalent in today's world may well be that 'a butterfly's wings in Argentina may cause a tornado in Mexico'. Ever since humans started questioning the system they belong to, the conclusion has always been that everything has an initial reason which affects the future but does not always make it predictable. In this sense, chaos theory makes sense of a term which is not only a mathematical phenomenon but also a key word that has just started being applied to the social sciences. The potential it carries in making us understand the world of social sciences is immense.

Though 'chaos' and 'complexity' have been mentioned for centuries and in different guises, they have never been as popular as in the 21 st century, the age of information, technology, communication, speed, networks, conflicts, digital born and so on. The Millennium Age has seen an explosion of human capacity in terms of the sheer velocity through which we are now able to instantly reach information that was previously inaccessible but to the most savvy or technologically gifted. As a natural consequence, habits, lifestyles, beliefs and even traditions are being redefined the world over. Beginning with the first ever televised war in history, the first Gulf War, human tragedy, pain or joy can now reverberate across the world in an instant, often causing emergency world summits, humanitarian campaigns and even military interventions in the name of protecting fellow human beings. It is a long road travelled from the stability of terror that characterized the Cold War, and it has brought with it new opportunities to alleviate human suffering as well as new challenges and questions regarding the power of the mighty and its abuse in the name of high ideals.

Change has therefore been introduced in a frantic pace, and the recent uprisings in the Middle East are a perfect example. When Muhammed Buazizi, a 24-year-old protester, burnt himself in Tunisia in 2010, he lit a fire in the brains of people in Arabic countries. Following that tragic incident, people, particularly the young, revolted against totalitarian governance, poor human rights, economic problems, and massive social inequity. Many of them demanded a say in the running of their countries, to be listened to and respected. Regardless of the eventual outcome of such revolts, diverse in nature and with unpredictable consequences, the recent past has shown that this was by no means an isolated phenomenon. The world over, not least in Europe and its periphery, masses of people have taken to the streets to voice their dissatisfaction with modern governance, even in those countries where parliamentary democracy and the rule of law seem well-entrenched. Often such protests have escalated into violent standoffs with state authorities, and old-style political machinations have achieved little in questing the thirst of people, and especially the young generation, for liberty, pluralism and an end to the scar of poverty and social exclusion that plagues so many of our contemporary societies. It was as if one could hear Aristotle whisper his phrase, seeking to remind us of the interconnected world in which we live. 
In such a chaotic and complex world, two scholars prominent at the international level, Şefika Şule Erçetin and Santo Banerjee, have assumed the task of editing a marvellous collection of essays dealing with the causes and consequences of our transformed political, economic and social/educational life. Their distinguished contribution to academia provides a guarantee of high quality scholarship in the pages that follow. Chaos and Complexity Theory in World Politics includes three main sections and a total of 25 chapters. The three sections are respectively entitled: 1- Chaos and Complexity in World Politics, 2- Uncertainty and Nonlinearity in Management and Economics, and 3-Chaos and Complexity in Society and Education.

In section one, you will find crucial political insights in terms of chaos and complexity theory concerning different parts of the world from Kazakhstan to Estonia, from Greece to Turkey. In the first chapter of Section 1, Şuay Nilhan Açıalın asserts the extent to which the euro crisis has had an effect on Greek social and economic life. She describes the social impact of the crisis on everyday people and discusses how strongly and deeply these effects have translated into popular frustration marred by a profound sense of disappointment with the political class of the country. In Emir Kaya's chapter, one can find a detailed description of what the author terms Turkey's dynamic secularism in terms of a nonlinear approach to law, state and governmental organizations. This is a crucially important issue for Turkey in the current conjuncture. Crisis, Crisophilia and Crisophilic are the terms employed by Beyazyüz, Erçetin and Albayrak in their chapter, inviting us to dwell deeply on their meaning and repercussions. Section One includes many more, important contributions on a range of timely subjects that will stimulate high interest. Key issues with regard to training the leaders, managers and planners who join peacekeeping operations in chaos environment are discussed in the chapter by Haydar Ateş, the differences and similarities of Kazakhstan and Estonia during and after their nation-building process are the focus of the contribution written by Cemile Asker, and an analytical insight to the yesterday, today and tomorrow of the Afghanistan conflict is discussed in another contribution by Haydar Ateş. Moreover, in chapter 7, Şefika Şule Erçetin, Mehmet Ali Hamedoğlu and Şuay Nilhan Açıkalın expand on the concept of managerial narcissism and depict its meaning and application in contemporary politics. Semra Günay Aktaş's chapter helps one understand the geography of suicide so as to design and implement effective suicide prevention policies. In the last chapter of section 1, 'Intibah' as an example of chaos in the desired change of society in literature is presented by M. Abdullah Özcan and Mehmet Özbaş.

Section 2 is entitled Uncertainty and Nonlinearity in Management and Economics. Leading researchers in their field Burhan Türkşen and İbrahim Özkan explain the ways in which it is possible to comprehend recent advances in the fuzzy system. Then Görkem Kaya delves into deep water in his economic analysis in terms of an investigation as to the Liquidity effect of Volatility Forecasting. Nilay Neyişci and Nihan Potas come in next, explaining how graduate students can cope with the inevitable uncertainty accompanying their study while Aleksei Panukalin outlines the key concepts behind a general theory of management in an innovative society.

Section 3, Chaos and Complexity in Society and Education, offers yet more elaborate and carefully drafted chapters. Adopting a comparative approach, chapters in this section offer a glimpse of the interpretation and application of chaos in different countries. Oğuzhan Karadeniz and Melike Faiz deeply investigate the differences and similarities of Social Studies Teacher Candidates' chaotic cases regarding social phenomena in Turkey and the United States in chapter 14. Bisaso offers a comparative analysis of human resource development systems in Uganda and Turkey, while Mahamadou Yahaya outlines a Niger case study regarding girls' education. Economic contributions to dropout problems as a chaotic case comparing Turkey and other countries is the main theme of the chapter written by Ilknur Maya, 
while Özdemir, Yirmibes and Turan preoccupy themselves with a thorough evaluation of instructors on the current position of Turkey in terms of its efforts to succeed in fulfilling the millennium development goals. Further, Chaos in Education is the interesting title of the contribution by Kayman, the extent to which peace is promoted in the social sciences curricula in Turkey and Greece forms the main subject of investigation by Karadeniz and Kaya, and the complex relationship between education, development and chaos is analysed by Çakır. Finally, adolescent suicide as a chaotic phenomenon is discussed by Halime Güngör, and Tuğba Küçüktamer offers valuable reflections on mobbing and chaotic reflections in international politics documents, among other insights offered in this section.

This collection of important essays defines situations in different countries in different contexts and makes an important contribution to our quest to understand how, when and why chaos and complexity intrude in our lives at different levels and with different effects. In a fast changing world, this volume helps us capture the meaning and consequences of chaotic conditions in a way that has hardly ever been tried out in the past. In doing so, it offers a glimpse on a rich variety of hot issues in world politics. It is a fantastic contribution to a subject that has received little attention thus far, and carries the potential of allowing a firm entry of chaos theory to the world of social sciences. For librarians and social scientists the world over, this book ought to become an indispensable tool of analysis and reflection.

Lastly, and apart from offering my best wishes for the success of this great volume, I wish to highlight the meticulous work by Şefika Şule Erçetin and Santo Banerjee in preparing such a worthy, interdisciplinary book. Their distinguished contribution is bound to leave a mark to the world of social sciences.

\section{Dimitris Tsarouhas}

Ankara, February 2014

\footnotetext{
Dimitris Tsarouhas is Acting Chair and Jean Monnet Chair in EU Politics at the Department of International Relations at Bilkent University, Turkey. He has previously taught at Middle East Technical University (METU) and has been a Visiting Fellow at Istanbul Bilgi University and Queen Mary, University of London. He is the author of Social Democracy in Sweden: the Threat from a Globalized World, co-editor of Bridging the Real Divide: Social and Regional Policy in Turkey's EU Accession Process, and author of numerous book chapters and journal articles on European Politics, Social and Employment Policy, and Public Policy. His work has also appeared in journals such as New Political Economy, Public Administration, Social Politics, Social Policy \& Administration and Southeast European and Black Sea Studies.
} 